only one topic, the evolution of clinical teaching in Vienna, is discussed.

For a variety of reasons, interest in medical education today is universal and significant reforms are being considered and introduced all over the world. But in order to appreciate fully the present situation, it is usually necessary to trace out their complex origins, proceeding from the simple to the complicated. Only by doing this can a full understanding of present day relationships, pressures, influences and of formative factors be achieved. Moreover, although conditions vary considerably from country to country, certain basic necessities are common, and the manner in which a problem presents and is tackled in one country may have relevance to reformers in another. The editor, recognizing the need medical educators have for an historical approach, has provided a book from which they will benefit greatly. As he points out, the only comparable treatise was published almost 80 years ago, by Theodor Puschmann, and has little interest for modern readers who are not concerned with history of medicine per se.

This book, however, not only brings the story up to modern times but also includes material which cannot be readily found elsewhere, and certainly not in English; thus, although the main trends and developments in many European countries are widely known, events in Asian countries have until now been little appreciated in the West. But Professor O'Malley realized that inevitably there would be many lacunae and it is hoped that his presentation will stimulate historians to fill them. In the case of Britain, for example, much has been written about the general developments, the metropolitan institutions and their conflicts, and about legal reform of the profession and its effects on medical education. We need in addition, however, much research into neglected areas: studies of the curricula and library and laboratory facilities as they reflect the diffusion of science into medicine; details of provincial training; the actual numbers of students, trainees, graduates, and the like; and on the whole a broader approach to many problems, based on the social, general historical, and economic elements rather than on medical issues and carried out by adequately experienced historians rather than by medical men.

In several ways, therefore, this book is an important contribution to the history of medicine and in particular it is informative and inspirational. It is also one of the last publications of Professor O'Malley, whose enthusiasm, erudition, and guidance in the field of medical history in general will be greatly missed in the future.

Edwin Clatike

\section{KING AMONG THE BLIND}

\section{Visual Perception}

By Torn N. Cornsweet. Pp. xiii +475 . (Academic: New York and London, May 1970.) $140 s$.

EVEN if there were room for argument as regards the readability of this beautifully produced book, there cannot be any about its legibility. The type is excellent. Tho illustrations (by Peter Howland) are beyond praise, and some have the smoothness of a lithograph. It is only in a state the soil of which had been trodden by the ardent emissaries of the Conquistadores, such as California, that a sardonic monocular skull could have been produced to illustrate the oculomotor system. Did I say monocular? It seems hardly credible that one of the most sophisticated of visual perceptions- -namely fused binocular vision to yield stereopsis - failed to get lodged in these extensive and informative pages, which modestly claim to include "the fundamental topics underlying the entire, broad field of visual perception". True, fusion is taken for granted in a sy'stem which, the author seems to believe, could convert monochromats into dichromats, and dichromats into trichromats. But otherwise we are one-eyed.

Having stressed what the book omits, I have to tell you what it covers. About 20 per cent of the book drals with threshold phenomena with special reference to the study of Hecht, Schlaer [sic] and Pireme. Another 14 per cent goes into a little photochemistry (with yet another magnificent artist's impression of molecular disruption), a trifle of receptor physiology, a weo bit of dark adaptation, a speck on spectral sensitivity, and a rather nice soupçon of Stiles-Crawford. The next 24 per cent enters into colour vision. The rest of the book deals essentially with spatial and temporal interaction, being illustrated by well thought out experiments, elever and also beautiful photographs, and it shows that Professor Cornsweet not only has this particular subject at his fingers' tips but also knows how to present it. This is really well worth reading.

The student will wish to concentrate on this section. The earlier parts give the impression that the author absorbs wisdom more readily from loud writers than from deep ones. His photochemistry is insufficient to prove to him the fallacy of Fig. 9.2k. And nowhere does he acknowledge the debt Figs. 8.12 et seq. owe to Willmer's pioneering thoughts. One would have liked to see some mention of small-field tritanopia- on which the evidence is good-and much more on tetrachromacy. Page 151 contains several factual errors, and I have read the original in vain to find where Purkinje states that he "passed white light through a prism and looked at the resulting spectrum during the early and the late stages of darkadaptation ....".

The final section is, however, well integrated, and the psychology of perception warmly shakes comparative biology by the hand. It contains a very good account of the theory and practice of modulation transfer functions and Cornsweet has spared no effort to produce one of the best introductions to the ins and outs of brightness that has yet been written. If the student finds the underlying physiology simplified, he should be grateful, and this, incidentally, is a feeling which many of us will share when we sense our several consciousnesses jogged by ideas they had not previously harboured.

R. A. WEALF

\section{A COMPLETE LABORATORY}

\section{Biochemistry of the Eye}

Edited by Clive N. Graymore. Pp. xiii + 783. (Acadomic: London and New York, June 1970.) 240s; $\$ 12$.

As Sir Stewart Duke Elder says of the eye in his foreword in this book, "This small and readily accessible organ contains in its restricted compass almost every type of metabolic reaction.... It is indeed a complete biochemical laboratory", and one is grateful to Dr Graymore and his team of contributors for collecting the basic information and the later advances together in one volume. The book contains chapters on the cornea (Maurice and Riley), the aqueous humour and ciliary body (Cole), the vitreous body (Berman and Voaden), biochemistry of vision (Bridges), biochemistry of the retina (Graymoro), inborn errors of metabolism affect ing the eye (Graymore and Hsia), nutritional aspects of the eyo (McLaren), and three chapters on the lens (Kuck). All the chapters are informative and well documented. The biochernistry of the separate parts of the eve is as different as their embryology and functions, and biochemists who are not already working with eye tissues may well find on reading this book that some part of the eye-the lens, the retina, the vitreous body-could provide a biochemical system that would help solve their problem. 